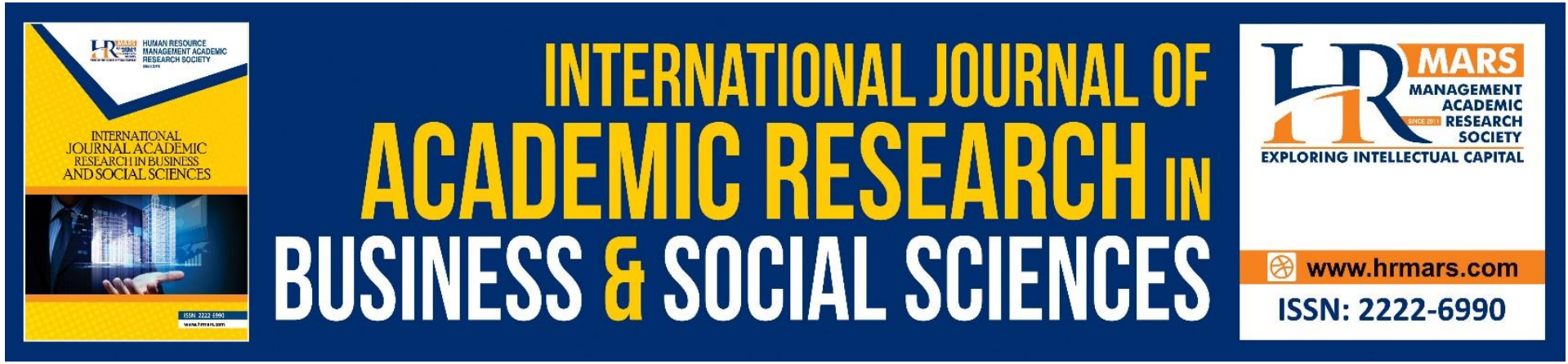

\title{
Causes for Delays in Municipal Projects in Jordan: A Case Study of the Zarqa Municipality
}

Ibrahim Moh'd (Al-Haj Hussein) Mofleh

To Link this Article: http://dx.doi.org/10.6007/IJARBSS/v11-i7/10509

DOI:10.6007/IJARBSS/v11-i7/10509

Received: 16 May 2021, Revised: 18 June 2021, Accepted: 15 July 2021

Published Online: 30 July 2021

In-Text Citation: (Mofleh, 2021)

To Cite this Article: Mofleh, I. M. (Al-H. H. (2021). Causes for Delays in Municipal Projects in Jordan: A Case Study of the Zarqa Municipality. International Journal of Academic Research in Business and Social Sciences, 11(7), 1312-1319.

Copyright: (c) 2021 The Author(s)

Published by Human Resource Management Academic Research Society (www.hrmars.com)

This article is published under the Creative Commons Attribution (CC BY 4.0) license. Anyone may reproduce, distribute, translate and create derivative works of this article (for both commercial and non-commercial purposes), subject to full attribution to the original publication and authors. The full terms of this license may be seen at: http://creativecommons.org/licences/by/4.0/legalcode

Vol. 11, No. 7, 2021, Pg. 1312 - 1319

http://hrmars.com/index.php/pages/detail/IJARBSS

JOURNAL HOMEPAGE

Full Terms \& Conditions of access and use can be found at http://hrmars.com/index.php/pages/detail/publication-ethics 


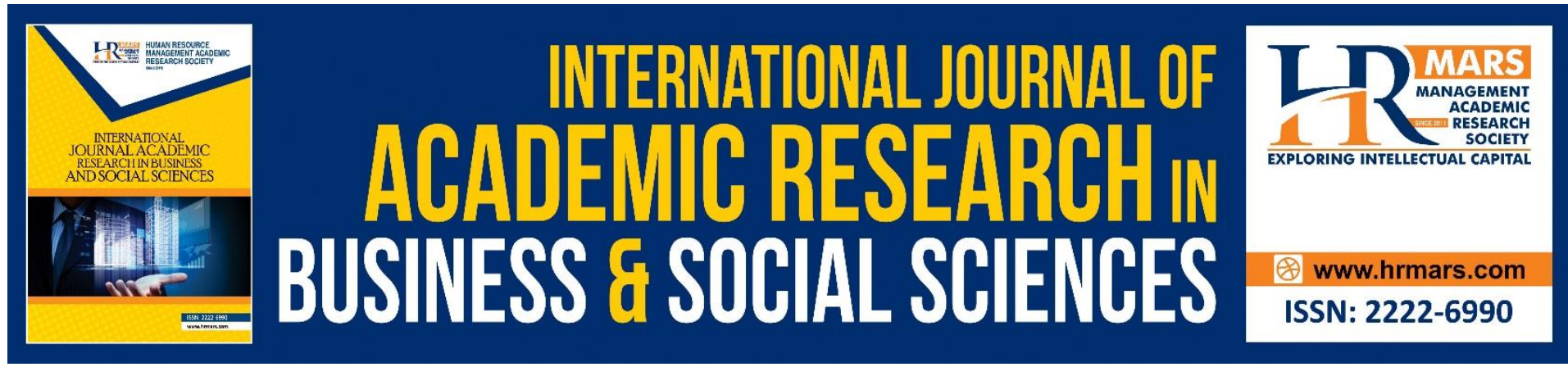

\title{
Causes for Delays in Municipal Projects in Jordan: A Case Study of the Zarqa Municipality
}

\author{
Ibrahim Moh'd (Al-Haj Hussein) Mofleh
}

Ph.D Candidate in Management Faculty of Business and Management (Universiti Sultan Zainal Abidin)

\begin{abstract}
Municipalities are considered among the most critical governmental institutions. They represent the local administration in any country and are in direct contact with citizens and stakeholders. They implement service and development projects in their related areas. This study aimed to investigate the causes for delaying projects in Zarqa Municipality as a case study, where a sample was chosen. A survey of personal interviews of 45 people representing government agencies, contractors, clients, and consultants, who were asked about the reasons for the delay was suggested by Odeh and Battaineh (2002). Respondents identified a group of the most important reasons for delaying projects, the most prominent of which are: Finance and payments of completed work, Inadequate contractor experience, Change orders, Mistakes and discrepancies in the contract document. This study reveals the decisive factors for delay facing the Jordanian municipalities in general, particularly the Zarqa municipality. The study presented a set of proposals to avoid these obstacles in the future.
\end{abstract}

Keywords: Municipalities, Projects, Causes for Delaying, Jordan.

\section{Introduction}

Usually, the process of implementing projects faces many obstacles, as it is considered a common global phenomenon that leads to problems in time and cost, which leads to a delay in the delivery of the project by contractors, and an increase in the costs incurred. Various sectors face these problems at the level of the public and private sectors. In developing countries, the public sector is more vulnerable than others to such problems.

In addition, delay in the implementation of public sector projects may lead to damage to the private sector, such as damage to commercial shops. This may raise many stakeholders, as stakeholders have a number of demands that must be met (Al Amosh, 2021). Which may damage the reputation of the public sector and raise compensation lawsuits, which leads to the public sector incurring more financial burdens due to the problems of delay in the delivery of projects.

In general, municipalities are one of the forms of local administration of countries, as they provide many services to citizens and it is directly related to them (Bordignon et al., 2003). The municipality is governed by a mayor and a municipality council consisting of a set councilor (i.e., elected political members). In addition, there is an administrative body, 
consisting of an administrative head of the municipality (called the municipality director) And another group of managers according to specialization (Eskerod et al., 2015).

Therefore, it is working on a number of projects that serve the local community, and faces a number of obstacles that may cause delay or failure of these projects. It may be attributed to reasons in implementing service and development projects required by the municipality's areas of non-approval of the municipality's budget and this limits the municipality's ability to bid for projects Also, the problems facing government-funded projects are often attributed to contractual and institutional failures that lead to time and cost overruns (Singh, 2010).

This study aims to investigate the delay of project in the Jordanian municipality of Zarqa as a model for the Jordanian municipalities.

\section{Literature Review}

Hamzah et al (2011) defined the delays in projects as "time overrun or extension of time to complete the project". Where government agencies usually suffer from delays in projects. According to Arabzad and Shirouyehzad (2012), the concept of project management should be developed by enhancing knowledge of design and implementation methods and standards. This requires a high qualification of the municipality's cadre, and extensive knowledge of the issues, dimensions and consequences associated with the implementation and management of projects.

On the other hand, the needs and expectations of stakeholders must be considered (Al Amosh and Mansor, 2021; Al Amosh and Mansor, 2018), and this is done through the efficient management of stakeholders to assess their needs and assess the extent to which the project is compatible with the aspirations of various stakeholders (Olander, 2007). The management of stakeholders in the implementation of municipal projects works on giving stakeholders feedback on the extent to which the project has achieved its societal objectives.

In a study conducted in America, Syed et al (2003) argued that the underlying reasons for the delay in the implementation of construction projects are the lack of prioritization and the distribution of roles and responsibilities in addition to the design process, which falls under the responsibility of the consultants. In another study conducted in South Africa, Larsen et al (2016) argued that project budgeting and financing is one of the main problems faced by construction projects within Zarqa Municipality area. The study included interviews with members of the Zarqa Municipality and local Department of Housing.

In another study carried out by Sambasivan \& Soon (2007), which included 150 respondents from clients, consultants and contractors, the results concluded that the reasons for the delay in the implementation of projects fall within 10 points: (1) contractor's improper planning, (2) contractor's poor site management, (3) inadequate contractor experience, (4) inadequate client's finance and payments for completed work, (5) problems with subcontractors, (6) shortage in material, (7) labor supply, (8) equipment availability and failure, (9) lack of communication between parties, and (10) mistakes during the construction stage. Also, there are six main effects of delay were: (1) time overrun, (2) cost overrun, (3) disputes, (4) arbitration, (5) litigation, and (6) total abandonment.

\section{Research Method}

This study uses the questionnaire as a tool for collecting study data, to identify the reasons for delays in projects for Zarqa municipality. The interview consists of two parts, the first section deals with questions about the basic and demographic information of respondents, 
while the second section contains the reasons behind the delay in projects. The interviews included 45 people related to Zarqa municipality projects.

\section{Results}

The biographical results of the study sample show that most of the individuals are between the ages of 40 and 49 years, meaning that they have good work experience, and $80 \%$ of the sample have a university education with a bachelor's degree, while only $2 \%$ hold a master's degree and the rest of the individuals hold a diploma. On the other hand, we note that most of the sample members are males, constituting $82 \%$ of the total sample, while only $18 \%$ of females. Most of the sample also included government employees and contractors who are knowledgeable enough. On the subject of the study, with regard to work experience, the table shows that $42 \%$ have experience ranging from 2-5 years, while $29 \%$ have experience between 6-10 years, and those who have experience more than 11 years were $16 \%$, and the field of specialization was as follows: 22\% Building, 49\% Infrastructure, 18\% Mechanical, 11\% Electrical.

Table 1: The demographic characteristic of the study sample

\begin{tabular}{|c|c|c|}
\hline Demographic characteristic & Frequency & $\%$ \\
\hline \multicolumn{3}{|l|}{ Age } \\
\hline $20-29$ & 4 & 9 \\
\hline $30-39$ & 14 & 31 \\
\hline $40-49$ & 17 & 38 \\
\hline 50 and above & 10 & 22 \\
\hline \multicolumn{3}{|l|}{ Sex } \\
\hline Male & 37 & 82 \\
\hline Female & 8 & 18 \\
\hline \multicolumn{3}{|l|}{ Education } \\
\hline Diploma & 8 & 18 \\
\hline BCS & 36 & 80 \\
\hline Master & 1 & 2 \\
\hline Ph.D & 0 & 0 \\
\hline \multicolumn{3}{|l|}{ Type of organization } \\
\hline Client & 12 & 27 \\
\hline Governmental & 13 & 29 \\
\hline Consultant & 3 & 6 \\
\hline Contractor & 17 & 38 \\
\hline \multicolumn{3}{|l|}{ Occupational level } \\
\hline Non-executive & 12 & 27 \\
\hline Executive & 21 & 46 \\
\hline Managerial & 12 & 27 \\
\hline \multicolumn{3}{|l|}{ Working experience } \\
\hline Less than 2 years & 6 & 13 \\
\hline $2-5$ & 19 & 42 \\
\hline $6-10$ & 13 & 29 \\
\hline 11 and above & 7 & 16 \\
\hline
\end{tabular}




\begin{tabular}{|l|l|l|}
\hline \multicolumn{2}{|l|}{ Field of specialization } & 22 \\
\hline Building & 10 & 22 \\
\hline Infrastructure & 22 & 49 \\
\hline Mechanical & 8 & 18 \\
\hline Electrical & 5 & 11 \\
\hline
\end{tabular}

\section{Causes for delaying Zarqa municipality projects}

The relative importance index (RII) was adopted and the model that Khoshgoftar et al. (2010) followed in their study (1) Finance and payments of completed work (RII=0.889), (2) Inadequate contractor experience ( $\mathrm{RII}=0.801),(3)$ Change orders (RII=0.794), (4) Mistakes and discrepancies in contract document (RII=0.787), (5) Labor supply (RII=0.786), (6) Mistakes during construction stage ( $R I=0.782)$, (7) Shortage in material (RII=0.782), (8) Preparation and approval of drawings (RII=0.754), (9) Equipment availability and failure (RII=0.744), (10) Inappropriate overall (RII=0.733).

Table 2: Causes of delay

\begin{tabular}{|c|c|c|c|c|c|c|c|}
\hline Causes of Delay & 1 & 2 & 3 & 4 & 5 & RII & Rank \\
\hline \multicolumn{8}{|c|}{ Client related causes } \\
\hline $\begin{array}{l}\text { Finance and } \\
\text { payments of } \\
\text { completed work }\end{array}$ & 0.7 & 2.7 & 6.6 & 32.9 & 40.8 & 0.889 & 1 \\
\hline $\begin{array}{l}\text { Owner } \\
\text { Interference }\end{array}$ & 1.3 & 18.5 & 22.5 & 17.9 & 30.2 & 0.717 & 12 \\
\hline $\begin{array}{l}\text { Slow decision } \\
\text { making }\end{array}$ & 2.8 & 24.4 & 33.3 & 41.5 & 29.6 & 0.709 & 14 \\
\hline $\begin{array}{l}\text { Unrealistic } \\
\text { contract duration } \\
\text { and requirements } \\
\text { imposed }\end{array}$ & 4.9 & 21.6 & 25.1 & 37.8 & 29.2 & 0.593 & 27 \\
\hline \multicolumn{8}{|c|}{ Contractor related causes } \\
\hline Subcontractors & 3.9 & 6.7 & 22.2 & 19.8 & 39.6 & 0.714 & 13 \\
\hline Site management & 4.1 & 10.6 & 12.8 & 40.8 & 34.2 & 0.627 & 23 \\
\hline $\begin{array}{l}\text { Construction } \\
\text { methods }\end{array}$ & 3.2 & 17.6 & 30.8 & 34.7 & 31.6 & 0.603 & 25 \\
\hline $\begin{array}{l}\text { Improper } \\
\text { planning }\end{array}$ & 3.9 & 12.1 & 28.7 & 31.5 & 39.9 & 0.683 & 19 \\
\hline $\begin{array}{l}\text { Mistakes during } \\
\text { construction } \\
\text { stage }\end{array}$ & 4.8 & 22.9 & 35.9 & 40.1 & 41.4 & 0.782 & 6 \\
\hline $\begin{array}{l}\text { Inadequate } \\
\text { contractor } \\
\text { experience }\end{array}$ & 4.5 & 16.5 & 26.7 & 27.3 & 36.2 & 0.801 & 2 \\
\hline \multicolumn{8}{|c|}{ Consultant related causes } \\
\hline $\begin{array}{l}\text { Contract } \\
\text { management }\end{array}$ & 0.8 & 14.6 & 20.2 & 35.9 & 34.2 & 0.667 & 20 \\
\hline
\end{tabular}


INTERNATIONAL JOURNAL OF ACADEMIC RESEARCH IN BUSINESS AND SOCIAL SCIENCES Vol. 11, No. 7, 2021, E-ISSN: 2222-6990 @ 2021 HRMARS

\begin{tabular}{|c|c|c|c|c|c|c|c|}
\hline $\begin{array}{lr}\text { Preparation } & \text { and } \\
\text { approval } & \text { of } \\
\text { drawings } & \\
\end{array}$ & 4.5 & 20.3 & 33.9 & 32.1 & 21.5 & 0.754 & 8 \\
\hline $\begin{array}{l}\text { Quality } \\
\text { assurance/control }\end{array}$ & 4.6 & 27.8 & 24.9 & 33.6 & 29.8 & 0.621 & 24 \\
\hline $\begin{array}{l}\text { Waiting time for } \\
\text { approval of tests } \\
\text { and inspection }\end{array}$ & 5.7 & 25.4 & 37.5 & 21.5 & 24.3 & 0.643 & 21 \\
\hline \multicolumn{8}{|c|}{ Material related causes } \\
\hline $\begin{array}{l}\text { Quality of } \\
\text { material }\end{array}$ & 0.6 & 17.9 & 21.2 & 19.5 & 31.2 & 0.601 & 26 \\
\hline $\begin{array}{l}\text { Shortage in } \\
\text { material }\end{array}$ & 1.2 & 19.5 & 12.3 & 21.7 & 31.6 & 0.766 & 7 \\
\hline \multicolumn{8}{|c|}{ Labor and equipment category causes } \\
\hline Labor supply & 1.5 & 22.3 & 16.5 & 20.8 & 31.2 & 0.786 & 5 \\
\hline $\begin{array}{l}\text { Labor } \\
\text { productivity }\end{array}$ & 3.5 & 18.4 & 19.2 & 20.3 & 17.4 & 0.775 & 6 \\
\hline $\begin{array}{l}\text { Equipment } \\
\text { availability and } \\
\text { failure }\end{array}$ & 4.2 & 15.6 & 12.7 & 19.3 & 22.9 & 0.744 & 9 \\
\hline \multicolumn{8}{|c|}{ Contract related causes } \\
\hline Change orders & 2.2 & 12.6 & 20.4 & 30.1 & 26.3 & 0.794 & 3 \\
\hline $\begin{array}{lr}\text { Mistakes and } \\
\text { discrepancies in } \\
\text { contract } & \\
\text { document } & \end{array}$ & 3.4 & 11.2 & 15.9 & 24.5 & 21.6 & 0.787 & 4 \\
\hline \multicolumn{8}{|c|}{ Contract relationships related causes } \\
\hline $\begin{array}{l}\text { Major disputes } \\
\text { and negotiations }\end{array}$ & 1.0 & 9.2 & 13.5 & 8.6 & 14.3 & 0.628 & 22 \\
\hline $\begin{array}{l}\text { Inappropriate } \\
\text { overall } \\
\text { organizational } \\
\text { structure linking } \\
\text { to the project }\end{array}$ & 1.3 & 12.5 & 17.2 & 26.9 & 33.2 & 0.733 & 10 \\
\hline $\begin{array}{l}\text { Lack of } \\
\text { communication } \\
\text { between the } \\
\text { parties }\end{array}$ & 3.6 & 14.4 & 12.6 & 22.5 & 26.1 & 0.729 & 11 \\
\hline \multicolumn{8}{|l|}{ External causes } \\
\hline $\begin{array}{l}\text { Weather } \\
\text { conditions }\end{array}$ & 4.4 & 22.6 & 18.8 & 29.5 & 35.5 & 0.691 & 18 \\
\hline $\begin{array}{l}\text { Regulatory } \\
\text { changes }\end{array}$ & 4.2 & 19.4 & 26.1 & 37.6 & 39.5 & 0.702 & 16 \\
\hline $\begin{array}{l}\text { Problem with } \\
\text { neighbors }\end{array}$ & 5.4 & 20.1 & 19.7 & 18.5 & 27.4 & 0.708 & 15 \\
\hline
\end{tabular}




\begin{tabular}{|l|l|l|l|l|l|l|l|}
\hline $\begin{array}{l}\text { Unforeseen site } \\
\text { conditions }\end{array}$ & 4.9 & 18.4 & 16.3 & 22.7 & 24.9 & 0.699 & 17 \\
\hline
\end{tabular}

\section{Conclusions and Recommendations}

This study aimed to assess the delay in the completion of projects of the Jordanian municipalities, and the municipality of Zarqa was decided as a case study, where a set of proposed factors were put forward based on studies of Odeh and Battaineh (2002), and Khoshgoftar et al. (2010). The results showed that the most important reasons for delaying projects in Zarqa municipality were poor funding and payments of completed work, lack of experience of contractors, change orders, mistakes and discrepancies in contract document, labor supply, mistakes during construction stage, shortage in material, preparation and approval of drawings, equipment availability and failure.

In this regard, I recommend reviewing and adjusting the project financing budget and trying to obtain more fantastic financial support to finance the projects implemented by the Zarqa Municipality, whether through government support or the support of international organizations and directing those projects to sustainable development, which will provide greater supporters for those projects. On the other hand, establishing special criteria that require appropriate experience for contractors and study their previous projects to avoid any future problems. Moreover, contracts must be prepared through specialized lawyers and engineers with expertise and competence to reach an ideal contract that guarantees the municipality and contractors' rights and is free from errors or vague phrases, and this will limit the resort to change orders. On the other hand, it must be ensured that there are qualified workers with contractors. Also, the supervisory staff must verify construction errors that may occur and not receive any work before it is completed as agreed upon in the contract.

The study has important implications for decision-makers in the municipalities of Jordan, especially the Zarqa municipality, and on contractors, and various stakeholders, as it provides an insight into the causes of delays in municipal projects, which are of great importance to citizens and various stakeholders, as municipal projects are often considered that with service and development goals. Therefore, the results of the study provide a clearer picture about the reasons for the delay in the implementation of projects, to avoid these obstacles in the future and to reach an ideal implementation of projects that serve the various parties. 


\section{References}

Al Amosh, H., \& Mansor, N. (2021). Disclosure of integrated reporting elements by industrial companies: evidence from Jordan. Journal of Management and Governance, 25(1), 121-145.

Al Amosh, H. A. M., \& Mansor, N. (2018). Sustainability and corporate reporting: A review on environmental and social accounting disclosure. International Journal of Accounting, 3(8), 78-87.

Al Amosh, H. A. (2021). The Role of Governance Attributes in Corporate Social Responsibility (CSR) Practices Evidence From Jordan. In Corporate Governance and Its Implications on Accounting and Finance (pp. 255-279). IGI Global.

Arabzad, S. M., \& Shirouyehzad, H. (2012). Improving project management process in municipality based on SWOT analysis. IACSIT International Journal of Engineering and Technology, 4(5), 607-612.

Bordignon, M., Cerniglia, F., \& Revelli, F. (2003). In search of yardstick competition: a spatial analysis of Italian municipality property tax setting. Journal of Urban Economics, 54(2), 199-217.

Olander, S. (2007). Stakeholder impact analysis in construction project management. Construction management and economics, 25(3), 277-287.

Odeh, A. M., \& Battaineh, H. T. (2002). Causes of construction delay: traditional contracts. International journal of project management, 20(1), 67-73.

Eskerod, P., Huemann, M., \& Ringhofer, C. (2015). Stakeholder inclusiveness: Enriching project management with general stakeholder theory1. Project Management Journal, 46(6), 42-53.

Hamzah, N., Khoiry, M. A., Arshad, I., Tawil, N. M., \& Ani, A. C. (2011). Cause of construction delay-Theoretical framework. Procedia engineering, 20, 490-495.

Khoshgoftar, M., Bakar, A. H. A., \& Osman, O. (2010). Causes of delays in Iranian construction projects. International Journal of Construction Management, 10(2), 53-69.

Larsen, J. K., Shen, G. Q., Lindhard, S. M., \& Brunoe, T. D. (2016). Factors affecting schedule delay, cost overrun, and quality level in public construction projects. Journal of management in engineering, 32(1), 04015032.

Singh, R. (2010). Delays and cost overruns in infrastructure projects: extent, causes and remedies. Economic and Political Weekly, 43-54.

Sambasivan, M., \& Soon, Y. W. (2007). Causes and effects of delays in Malaysian construction industry. International Journal of project management, 25(5), 517-526. 